Arab World English Journal (AWEJ) Volume 12. Number3 September 2021

DOI:https://dx.doi.org/10.24093/awej/vol12no3.26

Pp. $375-384$

\title{
Foreign Language Teaching of Ukrainian University Students in a Distance Learning Environment
}

\author{
Olena Pylypenko \\ Foreign Philology and Translation Department \\ National University of Life and Environmental Sciences of Ukraine \\ Kyiv, Ukraine \\ Liubov Kozub \\ Department of Foreign Languages for Mathematical Faculties \\ Taras Shevchenko National University of Kyiv \\ Ukraine \\ Corresponding Author: liubatern@yahoo.com
}

Received: 6/28/2021

Accepted: 9/21/2021

Published: 9/26/2021

\begin{abstract}
The Covid-19 pandemic has forced Ukraine, like other countries, to move to distance education. The study aims to analyze the distance learning experience of Ukrainian philology students, to find out the pros and cons of distance education, those things that motivate students, and the challenges they face while studying online. The survey consisted of a questionnaire and embraced 105 respondents. The survey goal was to collect data that would allow concluding about the effectiveness of distance education for Ukrainian philology students at the National University of Life and Environmental Sciences of Ukraine, particularly for the study of foreign languages. The significant results of the survey include: obtaining reliable data on the effectiveness of distance learning of Ukrainian philology students through their feedback in questionnaires, online testing, a variety of writing assignments, and assessment in the online classroom, finding out the most effective distance learning tools, the main features of teacher students interactions in a distance-learning environment. The research proves that Ukrainian philology students overall positively evaluate their distance learning experience. It does not negatively impact students' foreign language learning motivation. Despite a positive attitude to distance learning, Ukrainian philology students face particular challenges connected with access to devices, lack of information and communications technology skills, Internet connection, and lack of communication with their peers. The finding reveals, whatever are the benefits of distance education, it cannot entirely replace face-to-face learning.

Keywords: distance learning environment, educational technologies, foreign language teaching, Ukrainian university students
\end{abstract}

Cite as: Pylypenko, O., \& Kozub, L. (2021). Foreign Language Teaching of Ukrainian University Students in a Distance Learning Environment. Arab World English Journal, 12 (3) 375-384. DOI: https://dx.doi.org/10.24093/awej/vol12no3.26 


\section{Introduction}

The research shows that distance learning has been growing steadily worldwide over the last few years. It is mainly due to objective factors: the processes of globalization, democratization, humanization, and integration of society, the rapid development of digital technologies, and the lockdown caused by the COVID-19 pandemic. The development of Information Technologies (IT) has contributed to the emergence of new approaches to teaching and learning (Allen \& Seaman, 2017). The Internet gained a significant role in supporting remote workers, providing effective distance learning, and online collaboration (Favale, Soro, Trevisan, Drago, \& Mellia, 2020). Digitalization as a global phenomenon affects all spheres of life. It has become a trend in ensuring high living standards and contributed much to the sphere of education. It suggested various technical tools that made the learning process easier, faster, more creative, efficient, and innovative.

Therefore, this research aims to study the distance learning experience of Ukrainian philology students to find out the advantages and disadvantages of distance education, those things that motivate students, and the challenges they face while studying online. In our work, we considered the students' attitude towards the transition from in-person to online learning at the National University of Life and Environmental Sciences of Ukraine, whether it promotes or hinders their ability to master a foreign language. A deep insight into the problem will allow enhancing the teaching and learning process to become aware of the main features of online interactions and distance education. All this will contribute to the more effective usage of technology as a communication tool in foreign language classes and play a vital role in developing students' personalities and helping them become reflective and self-directed learners.

\section{Literature Review}

In times of pandemic, many researchers devoted their works to distance education and its concepts, as it has become an integral part of the educational system (Hodges, Moore, Lockee, Trust \& Bond, 2020; Ko \& Rossen, 2017). Scientists also pay considerable attention to distance learning challenges and solutions (Boettcher \& Conrad, 2016), peculiarities of teacher - student interaction in distance learning (Meißelbach \& Bochmann, 2020), distance learning methodology (Ferrer \& Kirschning, 2013), etc.

The transition to online learning due to COVID-19 evoked the interest of many Ukrainian scholars in online methodologies (Babelyuk 2020), the use of information technology in distance education (Kosovych, 2021), opportunities for self-education, self-organization, and selfdiscipline (Matvienko, Kuzmina, Yamchynska, \& Glazunova, 2020).

Analysis of numerous works devoted to distance learning proves that researchers do not share a standard view on the usage of terms denoting distance education. There is a wide range of alternative terms indicating this type of education: teaching at a distance (Vorobel \& Kim 2012), online teaching/ learning (Nilson \& Goodson, 2018), e-learning (Favale et al., 2020), distance education/ learning (Allen \& Seaman, 2017), Web-based learning (McKimm, Jollie, \& Cantillon, 2003), computer-based learning (Ally, 2009), Internet-based learning (Gernsbacher, 2015), etc. 
Providing a thorough analysis of distance learning, Singh and Thurman collected 46 definitions from 37 resources over 30 years, which allowed them to gain a deeper insight into the problem (Singh \& Thurman, 2019). Defining distance education at the beginning of the XXI century, Fillip (2001) claims it focuses on using various technologies (old and new) to facilitate learning at a distance. The researcher views distance education as a broader term that encompasses both distance learning and distance teaching.

Distance learning methods have changed with the emergence of new technologies. Modern distance education is a set of up-to-date electronic technologies that interactively provide information. It presupposes the use of information and communication technologies by teachers, scientists, professionals in different fields to send their message to students, listeners, or specialists in a particular sphere. The advent of online education has allowed researchers (Rekkedal et al., 2003) to supplement Keegan's (1996) definition of distance education with two components: computers and computer networks to connect and distribute learning materials, facilitate communication, thus establishing a dialogue between a student and a teacher.

Currently, scholars agree that at least five standard features we can trace in distance education (Keegan, 1996; Leleka \& Kapitan, 2021). Firstly, physical separation of a teacher and students throughout the learning process (this distinguishes distance education from traditional). Secondly, the educational institution plays a leading role in planning and preparing educational material and providing student support (this distinguishes distance education from self-learning and self-education programs). Thirdly, the application of various technologies to combine a teacher and students and provide an effective learning environment. Fourthly, the presence of two-way interaction between a teacher and students and, fifthly, almost the absence of traditional group work throughout the training. Considering the described features, we analyzed the peculiarities of Ukrainian students' foreign language study in a distance-learning environment.

\section{Methods}

To carry out this investigation, the researchers deliberately focused on analyzing students' perceptions of online learning, their ability to process information, and the use of a variety of online platforms. To get the objective results, we used a quantitative approach to data collection and a set of general scientific methods. Applying the observation method, we could summarize information about the main features of distant learning at the National University of Life and Environmental Sciences of Ukraine. The questionnaire method allowed us to involve many participants, to obtain accurate results, to collect the data we needed in the shortest time possible. The survey involved four groups of philology students: freshmen (36), sophomore (21), $3^{\text {rd }}$ year (15), and $4^{\text {th }}$ year (28) students. Thus, we collected the data from 105 Bachelor students: $74.5 \%$ female and $25.5 \%$ male participants.

\section{Research Procedures}

We carried out the research in May 2021 by questioning philology students on the organization of distance learning during the COVID-19 pandemic. We considered two aspects of the digitalization learning, the problems of multimedia technologies usage and the effectiveness of foreign language learning using digital technologies compared to traditional teaching methods. 
The survey presupposed the use of the questionnaire, one of the most reliable and commonly used methods in sociological research. The researchers made up questions to get overall feedback from the students, their motivations, and their interests in distance learning. Those were multiple-choice questions where respondents had to choose one of the suggested options.

However, it is essential to note that the questionnaire was not the only tool we used in the research. We took into consideration the whole study process during the pandemic that included online testing, a variety of writing assignments, and assessment in the online classroom. It allowed us to make reliable conclusions about the effectiveness of distance learning,

To host a survey, we used Microsoft Forms in Office 365 to understand better how students evaluate their learning experience and progress using distance technologies. To obtain the basic user information and collecting primary data, we used the Google Forms service. We distributed the questionnaire to informants on Viber, Telegram, Instagram, and by email.

The suggested questionnaire was anonymous and included the following questions:

1. How did you adapt to distance learning of a foreign language? Answer options: It was easy / I had some difficulties / It was difficult / I did not adapt at all.

2. Are you satisfied with the process of foreign language learning remotely? Answer options: Yes, I like it / Yes, but it is difficult / No, it is very difficult / No, it is too easy.

3. Which of the distance learning tools do you consider the most effective? Answer options: Online learning platforms (Moodle, Canvas, Google Classroom) / Messengers (Viber, Facebook Messenger, Telegram, WhatsApp) / Video conferencing apps (Zoom, Skype, Google Meet).

4. How do you get an assignment? Answer options: University platform Moodle / Messengers (Viber, Facebook Messenger, Telegram, WhatsApp) / E-mail / Other sources.

5. Can distance learning become part of the educational process in the future? Answer options: Yes / No / Difficult to answer.

6. Do you believe that online learning can replace face-to-face learning? Answer options: Yes / No / Not sure.

7. Can distance learning improve the level of education? Answer options: Yes / No / Not sure.

8. What are the advantages of distance learning? Answer options: Convenience of place, time, and pace of study / Accessibility / No need to attend lectures and seminars at the university / Less formal communication "teacher-student" / Comprehensive software / Leading educational technologies.

9. What are the disadvantages of distance learning of a foreign language? Answer options: Lack of personal communication with teachers and group-mates / Academic overload / Insufficient subject's content.

10. What interactive forms of distance learning do teachers use? Answer options: University platform Moodle / Online lectures / Webinars / Online presentations.

\section{Results}

The survey analysis showed that for $35.3 \%$ of students, the process of adaptation to distance learning was easy; $49 \%$ admitted that they adapted well to this educational format. However, they had some difficulties; 9.8\% answered it was difficult to adjust, 5.3\% acknowledged they did not adapt to distance learning. 
Answering the question on the satisfaction with the study of a foreign language online, $64.7 \%$ admitted they liked it, $23 \%$ of students found it convenient but a little complicated. For $8 \%$ of students, learning a foreign language remotely turned out to be very difficult. On the contrary, $4 \%$ confessed to study online was too easy for them.

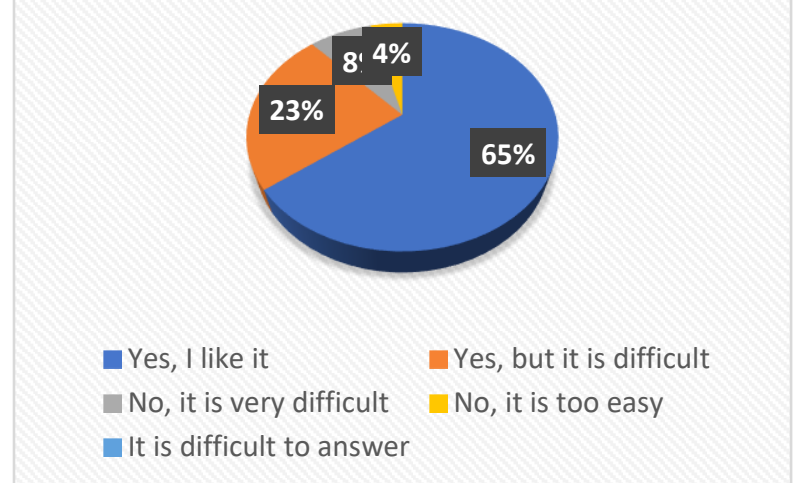

Figure 1. Frequency distribution of indicators related to students' satisfaction with the study of a foreign language remotely

Considering the advantages of distance learning, most students admitted that it allows them to learn at their own pace in a relaxed environment. In this respect, $62.7 \%$ chose the convenience of place, time, and pace study option; $13.7 \%$ noted its accessibility. For the same amount of students $(7.8 \%)$, it is essential that distance learning does not require attending lectures and seminars at the university. Thus, it is not so time-consuming. At the same time, they consider that online study allows them to establish more friendly relationships with their teachers, addressing them less formally, omitting the patronymic, which is typical to Ukrainian culture. Among the advantages, 5.9\% of respondents mentioned leading educational technologies and $2.0 \%$ comprehensive software.

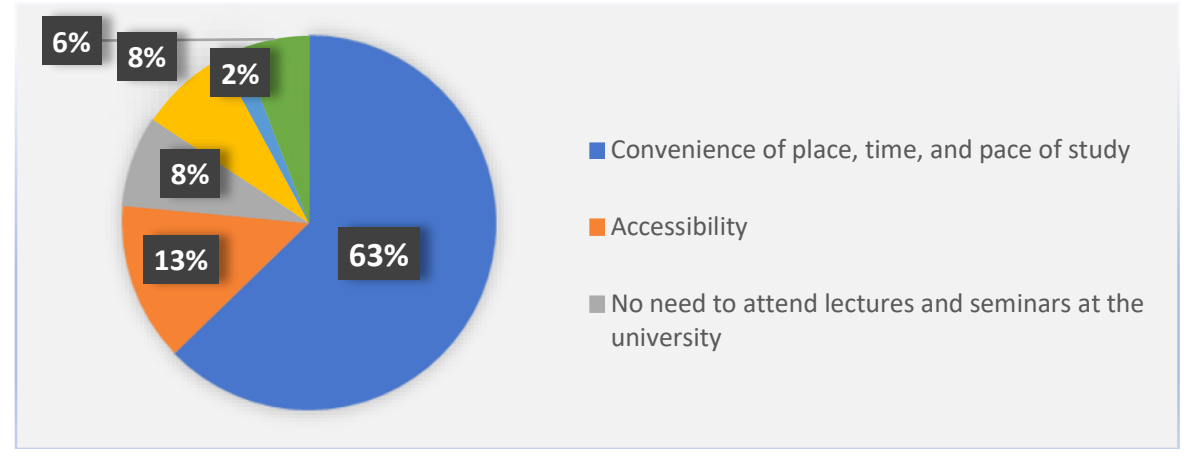

Figure 2. Frequency distribution of indicators related to students' answers on advantages of distance learning

Analyzing the difficulties students encountered during distance learning, $64.7 \%$ of them mentioned a lack of personal communication with teachers and group-mates. Thus, overcoming communication difficulties while studying online appeared to be one of the burning problems, especially for first-year students. They had to adapt to new circumstances and rules of study without having an opportunity to attend the university and being devoid of personal 
communication with their peers. Academic overload ranks second among the disadvantages of distance learning, constituting $23.5 \%$. Insufficient subject content mentioned $12 \%$ of students. Commenting on the drawbacks of distance learning, some respondents complained of technical problems and the lack of a permanent Internet connection that interfered with the learning process.

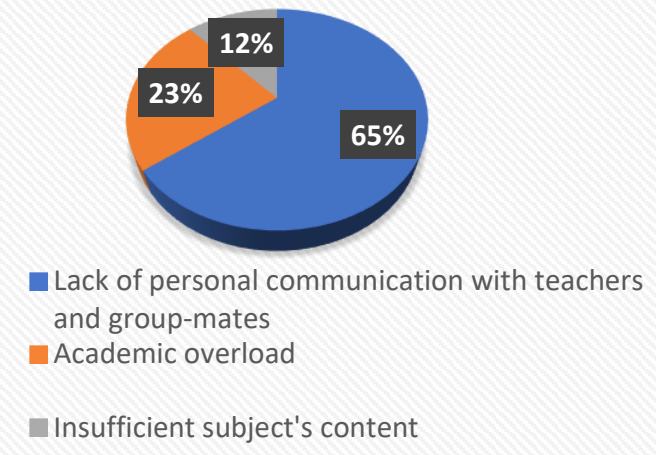

Figure 3. Frequency distribution of indicators related to students' answers on the disadvantages of distance learning of a foreign language

The survey revealed that society is still quite wary of the quality of distance learning, although students are mostly satisfied with it. The criteria and perceptions of the quality of education in different social groups may differ. Due to the specifics of the philological profession, the communicative activity is a necessary and compulsory part of students' education. In light of this, it is essential to identify social areas that can compensate for the lack of communication and provide sufficient opportunities for socialization. Analyzing the most effective distance learning tools, 52.9\% of respondents named online learning platforms (Moodle, Canvas, Google Classroom, Google Meet), 31.4\% preferred video conferencing apps (Zoom, Skype, Meet Hangouts), 15.7\% chose in favor of Messengers (Viber, Facebook Messenger, Telegram, WhatsApp).

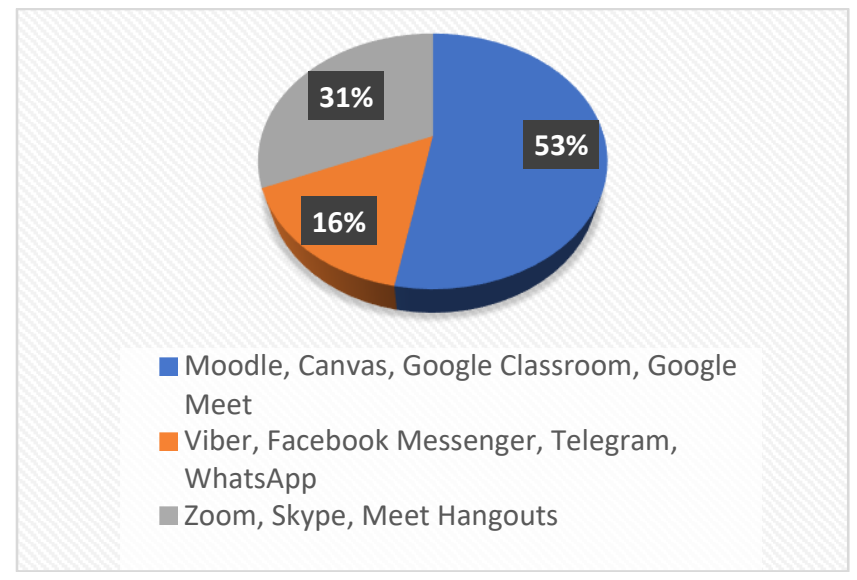

Figure 4. Frequency distribution of indicators related to students' answers on the most effective distance learning tools 
Analyzing the interactive forms of distance learning preferable by foreign language teachers, most students (62.7\%) indicated the university platform Moodle. The choice is quite logical, taking into consideration that this platform is convenient for work. The teachers can easily upload texts, audio and video files, images, presentations, etc. They can also create lectures, tests, and surveys for courses using the platform, which allows customizing the system for oneself and contains only the necessary parameters. Among other interactive forms of distance learning used by teachers, students mentioned presentations (66.7\%) and online lectures (54.9\%). The smallest but still a considerable share constitute webinars (29.4\%).

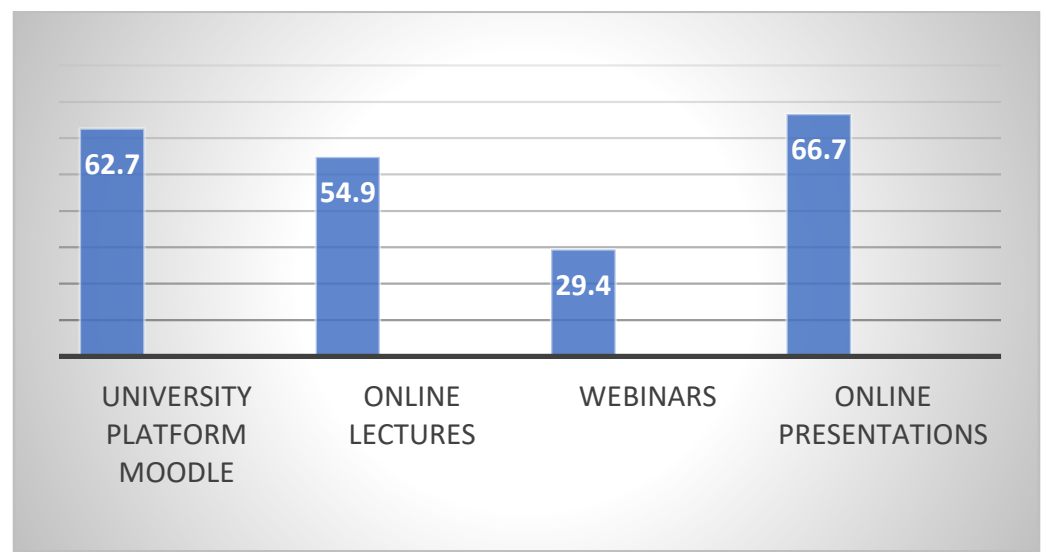

Figure 5. Frequency distribution of indicators related to students' answers on interactive teaching methods in distance learning

Considering the impact of distance learning on the quality of education, 39\% of students evaluated it positively, $31.4 \%$ of respondents hesitated to answer, $29.4 \%$ stated that it did not improve the quality of their study, their skills, and it did not contribute to their effective professional development.

It is interesting to note that the same amount of students gave opposite answers to the question about face-to-face versus online learning. 37,3\% found distance learning quite appealing and expressed an opinion that it could replace traditional education. However, many students found it unacceptable, stating that personal interaction is crucial and one cannot substitute it with online communication. $25.4 \%$ of respondents were hesitant to answer.

Though, the majority (68.6\%) of students are satisfied with the organization of distance learning during the pandemic, they believe it would be better to combine the virtual training with traditional education. At the same time, $13.7 \%$ of students preferred to return to their classrooms, $17.6 \%$ hesitated to answer.

\section{Discussion}

The survey results showed that Ukrainian philology students recognize the need to use distance learning for foreign languages acquisition during the COVID-19 pandemic. They are aware of the benefits of distance learning, fairly quickly mastered the tools of the university platform Moodle, adjusted to online study using different video conferencing apps and Messengers. The obtained results allow to draw a parallel between our research and the views 
expressed by German students who confirmed the effectiveness of distance learning (Meißelbach \& Bochmann, 2020) using a variety of distance learning tools. The important roles of videoconferencing platforms Zoom, Skype, Google Meet during the COVID-19 lockdown allowed the Norwegian researchers (Langhold \& Damsa, 2020) to talk about the "ZOOM revolution" in distance education.

According to the survey, the lack of direct contact between teachers and students is one of the main problems in distance learning. It is a decisive factor that causes psychological problems (Stegbauer, 2020). The lack of Information and Communication Technology (ICT) literacy of Ukrainian philology students is another factor that leads to problems during distance learning. It confirms the findings of other researchers, who state the low level of ICT competence of philology students comparing to lawyers, economists, and engineers (Senkbeil et al., 2019).

Distance learning is today's challenge for educators around the world (Hodges, Moore, Lockee, Trust \& Bond, 2020; Lörz, Marczuk, Zimmer, Multrus, \& Buchholz, 2020). It becomes clear that after the pandemic the society will not return to conventional form of education. Despite the positive results of online education, both teachers and students agree that it is impossible to replace the traditional classroom. In the future, there will likely be a new model of the combination of online and offline study, the integration of inside and outside the classroom.

\section{Conclusion}

Since the COVID-19 outbreak, distance learning has shown significant growth. An increasing number of schools and universities worldwide provide distance learning opportunities to ensure the educational process and allow students to gain new skills. The study of the distance learning experience of Ukrainian philology students allowed assessing its effectiveness, the pros and cons of distance education, the things that motivate students, and the challenges they face while learning online. We can draw the following conclusions after analyzing the obtained results. We found out that Ukrainian students overall positively evaluate their distance learning experience. However, they admit that the study of a foreign language remotely requires a lot of efforts and motivation. At the same time, they believe that distance learning did not affect their foreign language learning motivation. Processing the students' responses to the questions surveyed in the questionnaire, we found out that online learning mostly impedes their effective communication and cannot be a substitute for face-to-face interaction. Among challenges of distance education, Ukrainian philology students mentioned access to devices in case of a few children in a family, lack of information and communications technology skills, and Internet connection. However, the finding confirms that the Ukrainian education system has a positive tendency of development, demonstrates readiness to distance education, and increases the level of professional and pedagogical competence of university teachers.

\section{About the Authors}

Olena Pylypenko, PhD in Pedagogy, Associate Professor at Foreign Philology and Translation Department, National University of Life and Environmental Sciences of Ukraine. Her areas of interest include means of foreign language teaching, competency-based education, pedagogy and education. https://orcid.org/0000-0002-6249-912

Liubov Kozub, PhD in Philology, Associate Professor at Department of Foreign Languages for 
Mathematical Faculties, Taras Shevchenko National University of Kyiv. Her research interests are in the area of experimental phonetics, sociolinguistics, pragmatics, text linguistics, innovative methods of teaching English for specific purposes. http://orcid.org/0000-0002-6617-6442

\section{References}

Allen, I. E., \& Seaman, J. (2017). Digital Learning Compass: Distance Education Enrollment Report 2017. Retrieved from https://files.eric.ed.gov/fulltext/ED580868.pdf

Ally, M. (2009). Designing Effective Computer-Based Learning Materials. In M. Mills \& D. Wake. (Eds.), Encyclopedia of Distance Learning. (2 ${ }^{\text {nd }}$ ed., pp. 571-579). IGI Global. DOI:10.4018/978-1-60566-198-8.ch083

Babelyuk, O. A., Koliasa, O. V., Kushlyk, O. P., \& Smaglii, V. M. (2020). Using Distance EdTech for Remote Foreign Language Teaching During the COVID-19 Lockdown in Ukraine. Arab World English Journal. Special Issue on the English Language in Ukrainian Context, 4-15. DOI: https://dx.doi.org/10.24093/awej/elt3.1

Boettcher, J.V., Conrad, R. M. (2016). The Online Teaching Survival Guide: Simple and Practical Pedagogical Tips. New York: John Wiley \& Sons Inc.

Favale, T., Soro, F., Trevisan, M., Drago, I., \& Mellia, M. (2020). Campus Traffic and ELearning during COVID-19 Pandemic. Computer Networks, 176, 2-26. https://doi.org/10.1016/j.comnet.2020.107290

Ferrer, E., \& Kirschning, I. (2013). A Methodology for the Development of Distance Learning Tasks Adaptable to the Student's Learning Style. Procedia - Social and Behavioral Sciences, 141, 518-523.

Fillip, B. (2001). Distance Education in Central America and the Caribbean: Making the Most of the Region's Experience and Tackling Challenges and Opportunities of the New Information and Communication Technologies. Tokyo, Japan, and Washington, DC: Japan International Cooperation Agency.

Gernsbacher, M.A. (2015). Why Internet-Based Education? Frontiers in Psychology, 5, 2-4. DOI:10.3389/fpsyg.2014.01530

Hodges, Ch., Moore, S., Lockee, B., Trust, T., \& Bond, A. (2020). The Difference Between Emergency Remote Teaching and Online Learning. Retrieved from https://er.educause.edu/articles/2020/3/the-difference-between-emergency-remoteteaching-and-online-learning

Keegan, D. (1996). Foundations of Distance Education ( $3^{\text {rd }}$ ed.). New York and London: Routledge.

Ko, S., \& Rossen, S. (2017). Teaching Online. A Practical Guide (4 ${ }^{\text {th }}$ ed.). New York and London: Routledge.

Kosovych, O. (2021). Problems of Distance Learning of Foreign Languages in Times of Pandemic. Modern Trends in Foreign Language Training of Future Non-Language Specialists in a Multicultural Environment. Materials of the VII International Scientific and Practical Conference, 140-148.

Langfold, M., \& Damsa, C. (2020). Online Teaching in the Time of Covid-19. Academic teachers' experiences in Norway. Retrieved from https://www.jus.uio.no/cell/ressurser/evaluering/rapporter/report-university-teachers160420-with-annex.pdf 
Leleka, T. \& Kapitan T. (2021). The Features of Distance Learning in Higher Education System. Pedagogy and Education Management Review, 1(3), 18-25. https://doi.org/10.36690/2733-2039-2021-1-18

Lörz, M., Marczuk, A., Zimmer, L., Multrus, F., \& Buchholz, S. (2020). Studieren unter CoronaBedingungen: Studierende bewerten das erste Digitalsemester. DZHW Brief. 5. Hannover: DZHW. Retrieved from https://www.dzhw.eu/pdf/pub_brief/dzhw_brief_05_2020.pdf

Matvienko, O., Kuzmina, S., Yamchynska, T., \& Glazunova, T. (2020). Ukrainian Universities Under the Pressure of Pandemic: The Effect of Pandemic on Teacher Leadership, Selfeducation, and Lifelong Learning. Proceedings of 6th ICLEL Conference 2020, 463-473. Retrieved from https://faf348ef-5904-4b29-9cf998b675786628.filesusr.com/ugd/d546b1_7384fbcb4f9a4c6981f56c0d6431fff2.pdf

Meißelbach, C., \& Bochmann, C. (2020). Wir können hier alle nur dazulernen. Studierendenbefragung zur digitalen Lehre in Zeiten der Corona Krise. Dresden: Technische Universität Dresden. Retrieved from https://tudresden.de/gsw/phil/powi/polsys/ressourcen/dateien/forschung/umfrage-digitalelehre/studierendenbefragung-digitale-lehre.pdf?lang=en

McKimm, J., Jollie, C., \& Cantillon, P. (2003). Web-based learning. British Medical Journal, 326, 870-873. DOI: $10.1136 / \mathrm{bmj} .326 .7394 .870$

Nilson, L.B., \& Goodson, L.A. (2018). Online Teaching at Its Best: Merging Instructional Design with Teaching and Learning Research. New York: John Wiley \& Sons Inc.

Rekkedal, T., et al. (2003). Internet-Based E-learning, Pedagogy, and Support Systems. Norway: NKI Distance Education.

Senkbeil, J. I. M., \& Schöber Ch. (2019). Wie gut sind angehende und fortgeschrittene Studierende auf das Leben und Arbeiten in der digitalen Welt vorbereitet? Ergebnisse eines Standard Setting-Verfahrens zur Beschreibung von ICT-bezogenen Kompetenzniveaus. Zeitschrift für Erziehungswissenschaft, 22. 1359-1384.

Singh, V., \& Thurman, A. (2019). How Many Ways Can We Define Online Learning? A Systematic Literature Review of Definitions of Online Learning (1988-2018). American Journal of Distance Education, 33(4), 289-306. https://doi.org/10.1080/08923647.2019.1663082

Stegbauer, C. (2020). Netzwerkungleichheit, die Verbreitung des Virus und wer in Gefahr ist. In C. Stegbauer \& I. Clemens (Hrsg.). Corona-Netzwerke: Gesellschaft im Zeichen des Virus, 15-26.

Vorobel, O., \& Kim, D. (2012). Language Teaching at a Distance: An Overview of Research. CALICO Journal, 29(3), 548-562. DOI:10.11139/cj.29.3.548-562 